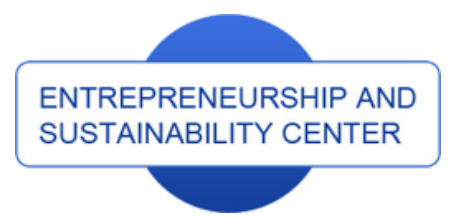

Publisher

http://jssidoi.org/esc/home

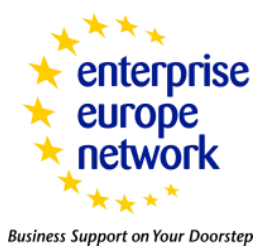

CASPA

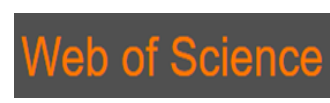

1) Clarivate

\title{
PECULIARITIES OF ILLEGAL IMMIGRANT'S INTRUSIONS INTO ROAD FREIGHT TRANSPORT UNITS IN THE FRANCE - UK CORRIDOR
}

\author{
Margarita Marija Lietuvniké , Aidas Vasilis Vasiliauskas², Virgilija Vasilienè-Vasiliauskiené $\dot{3}^{3}$ Jolanta \\ Sabaityte $\dot{e}^{4}$ \\ 1,2,3,4 Vilnius Gediminas Technical University, 11 Saulètekio al., LT-10223, Vilnius, Lithuania \\ E-mails: ${ }^{1}$ margarita.smile@gmail.com; ${ }^{2}$ aidas.vasilis-vasiliauskas@vgtu.lt; ${ }^{3}$ virgilija.vasiliene-vasiliauskiene@vgtu.lt; \\ ${ }^{4}$ jolanta.sabaityte@vgtu.lt
}

Received 18 October 2017; accepted 20 February 2018; published 30 March 2018

\begin{abstract}
The World Economic Crisis has increased such processes as poverty, discrimination and war. As a consequence, many people from Africa, Middle East and Asia started to immigrate to Europe. There were over one million unauthorized immigrants entering Europe in 2015. However, not all countries want and can accept refugees. A long-time frame for assessing asylum applications or frequent rejections encourages refugees to migrate illegally by intruding freight transport units to cross the border of their chosen European country. The intrusion of illegal immigrants into road freight units to cross borders without being noticed has caused a great deal of damage to the international freight transportation companies. This article presents results of the study aimed at investigation of peculiarities of illegal immigrant's intrusions into road freight transport units moving along the corridor France - United Kingdom.
\end{abstract}

Keywords: refugees, illegal immigrants, European migrant crisis, road freight transport, road freight transport risks, human factor.

Reference to this paper should be made as follows: Lietuvnikè, M. M.; Vasilis Vasiliauskas, A.; Vasilienè-Vasiliauskienė, V.; Sabaitytė, J. 2018. Peculiarities of illegal immigrant's intrusions into road freight transport units in the France - UK corridor, Entrepreneurship and Sustainability Issues 5(3): 634-647. http://doi.org/10.9770/jesi.2018.5.3(16)

JEL Classifications: R11, R41, 019

Additional disciplines (besides field of economics reflected in JEL classifications): transport engineering; environmental engineering.

\section{Introduction}

The World Economic Crisis has increased such processes as poverty, discrimination and war. As a consequence, many people from Africa, Middle East and Asia started to immigrate to Europe. There were over one million 
The International Journal

ENTREPRENEURSHIP AND SUSTAINABILITY ISSUES

ISSN 2345-0282 (online) http://jssidoi.org/jesi/

2018 Volume 5 Number 3 (March)

http://doi.org/10.9770/jesi.2018.5.3(16)

unauthorized immigrants entering Europe in 2015. However, not all EU countries want and can accept refugees. A long-time frame for assessing asylum applications or frequent rejections encourages refugees to migrate illegally, by intruding freight transport units, to cross the border of their chosen European country.

Illegal migration is noticed all over the world in all transport modes. Meanwhile European migrant crisis mainly touch land transportation by road and rail freight transport, ignoring the rest. The intrusion of illegal immigrants into road freight vehicles to cross borders without being noticed has caused a great deal of damage to road freight transportation companies, involving property and cargo damage, physical and psychological violence against drivers, etc. Currently, the debates over the problems caused by illegal immigrants to European road freight transport companies are not widely addressed.

This article presents results of the study aimed at investigation of peculiarities of illegal immigrant's intrusions into road freight transport units moving along the corridor France - United Kingdom (through the Port of Calais).

The purpose of the research described in this paper is to highlight the tendencies of intrusions to the road freight transport unit and identify riskiest spots, where such incidents take place.

The first chapter of this article analyses current state and reasons behind the European migrant crisis. Conclusion is made that part of immigrants do not intend to stay in the first country of the EU they had arrived to, but rather are trying to get to these, which offer better social conditions and living standards. As a consequence, part of these immigrants tries to get to a "promised land" illegally. Next chapter discusses importance of road freight transport in the process of relocation of migrants and identifies types of risks that might occur during the process of transportation. Third chapter starts with a brief description of methodology that was applied to investigate situation on the route France - UK, and then continues with presentation of obtained results pointing out peculiarities of illegal immigrant's intrusions into road freight transport units. The article ends with presentation of risk map and summarizing conclusions.

\section{State of the art and reasons behind the European migrant crisis}

The European migrant crisis, or the European refugee crisis, is a term given to a period beginning in 2015 when rising numbers of people arrived in the European Union (EU).

Human migration - is the movement of people from one place to another with the intention of settling in a new place. Migration is a constant feature of evolving mankind history - homo-migrants are described since the homo sapiens times (Bade \& Münz, 2000; King \& Lulle, 2016; Tumalavičius, Nikolayevskyy, \& Endziņš, 2017).

According to P. J. Oiarzabal and U. D. Reips (2012), migration can be conducted individually, in families or large groups. Harzig, Hoerder, and Gabaccia (2009) claim that modern human mobility enables both - micro and macro migration.

As suggested by U. D. Reips and L. Buffardi (2012), it is possible to distinguish types of migration based on psychology: voluntary and forced. D. Courgeau-Andevalelievre (2016) states that voluntary migration is based on an internal self-help system and depends on how strongly an individual convinces himself/herself that migration will improve his/her life quality.

Meanwhile, forced migration is caused by an individual's psychological fears due to certain factors surrounding the environment that threaten his well-being or life (Banaitė \& Tamošiūnienė, 2016; King \& Lulle, 2016; (Banaitė 
\& Tamošiūnienė, 2016; King \& Lulle, 2016; Shuaibu \& Oladayo, 2016; Świerczyńska, 2017; Tvaronavičienė \& Černevičiūtè, 2015; Kot \& Pigoń, 2014, Androniceanu, 2017). People who have experienced psychological or physical abuse feel forced to migrate, which is why the psyche of such people is often impaired. These individuals are difficult to predict and can lead to various difficulties, which can cause much damage to both political and administrative units (Courgeau \& Lelièvre, 2006; Masood \& Nijkamp, 2017; Carra et al., 2016).

When the discussion comes to the EU migrant crisis, rather than referring to economic migrants, who are looking for better lives, it discusses people, who try to save their lives (such as refugees and asylum seekers). The root reasons for forced migration, were hidden in 2007 world-wide financial crisis, civil wars in the South-East (Syria, Iraque, Iran, Afghanistan, Pakistan, etc.), and natural disasters (droughts, floods, earthquakes, hurricanes, etc.) in Africa (Lake Chad Basin, South Sudan, Somalia, etc.). All these factors brought hunger, poverty, discrimination, persecution and wars. By the UN Refugee agency 65,3 million people, or 1 person in 113 were displaced from their homes by conflict and persecution in 2015 (King \& Lulle, 2016). This number of people movement is the highest level since World War II.

Most of the migrants came from the Muslim-majority countries of regions in the South and East of Europe, as well as Western Asia, South Asia and Africa.

According to the United Nations High Commission for Refugees, the main countries from which refugees comes to the EU are Syria, Afganistan, Somalia, Sudan, South-Sudan, Congo Dem.Rep., Centrl African republic, Iraque, Eritrea, Pakistan and etc. European countries, which are mainly reached by refugees first, are Italy and Greece. It is due to a comfortable geographic position, between South-East Europe and Africa (see figure 1).

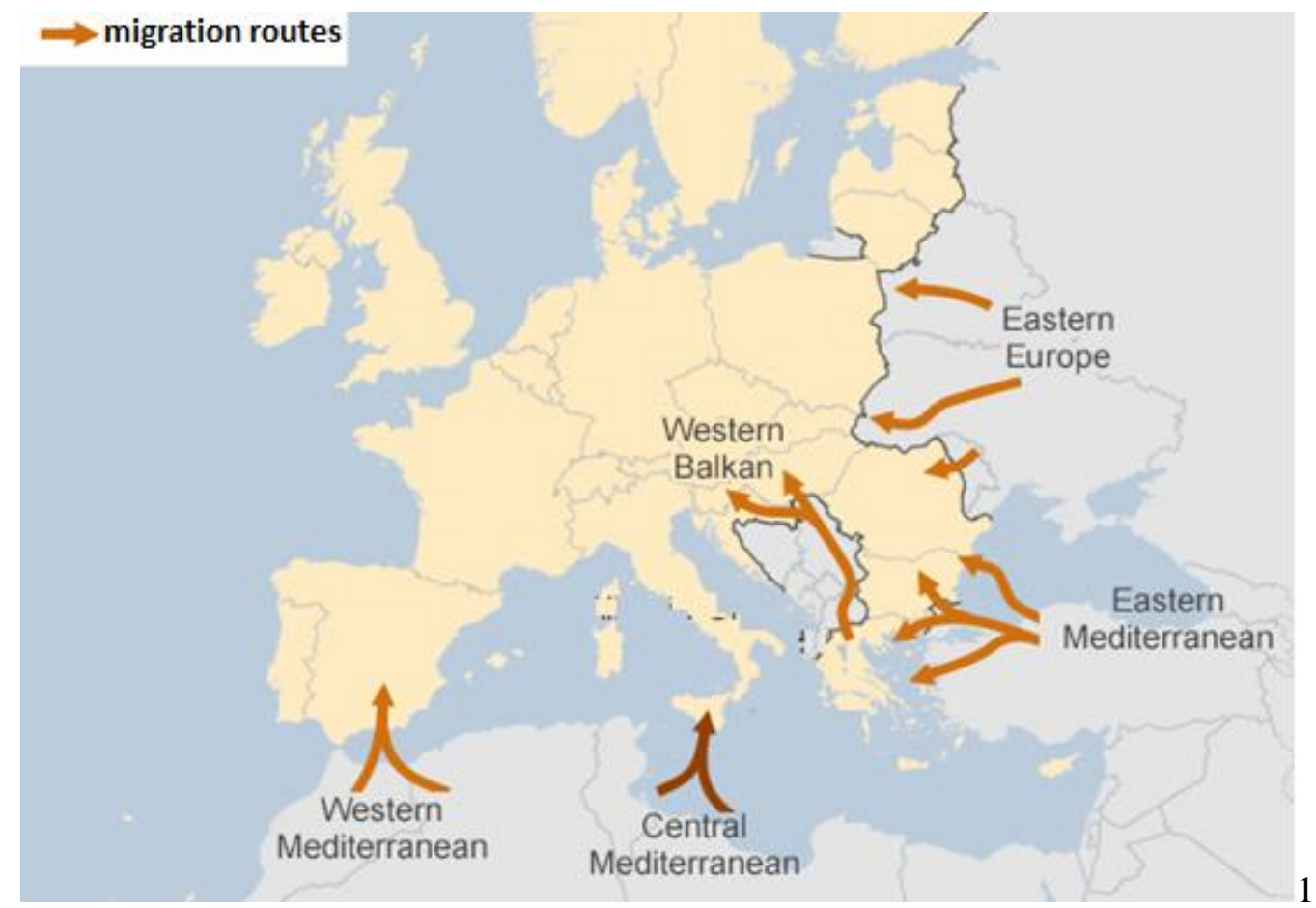

Fig. 1. Main migrant's paths to the EU

Source: Kobler, 2017 
The International Journal

ENTREPRENEURSHIP AND SUSTAINABILITY ISSUES

ISSN 2345-0282 (online) http://jssidoi.org/jesi/

2018 Volume 5 Number 3 (March)

http://doi.org/10.9770/jesi.2018.5.3(16)

It is important to note, that Italy and Greece are just the first stop, as the purpose is to move to countries with better social benefits, and familiar languages.

According to Eurostat (2016) EU member states received over 1.39 million first-time asylum applications in 2015, more than double that of the previous year. Five states Germany, Hungary, Sweden, Austria, Great Britain) received around two-thirds of the EU's asylum applications in 2015 (UNHCR - The UN Refugee Agency, 2017).

Assessing the number of registered asylum applications and the number of registered refugees arriving to Europe from 2008 to 2015, it can be noted that not all arrivals submit applications for asylum. This leads to the conclusion that those, who did not submit asylum applications, will settle in and stay in the country illegally or hide from the law migrating between European countries, using illegal methods. Routes which illegal immigrants use in order to reach their final destination in the EU are presented in figure 2.

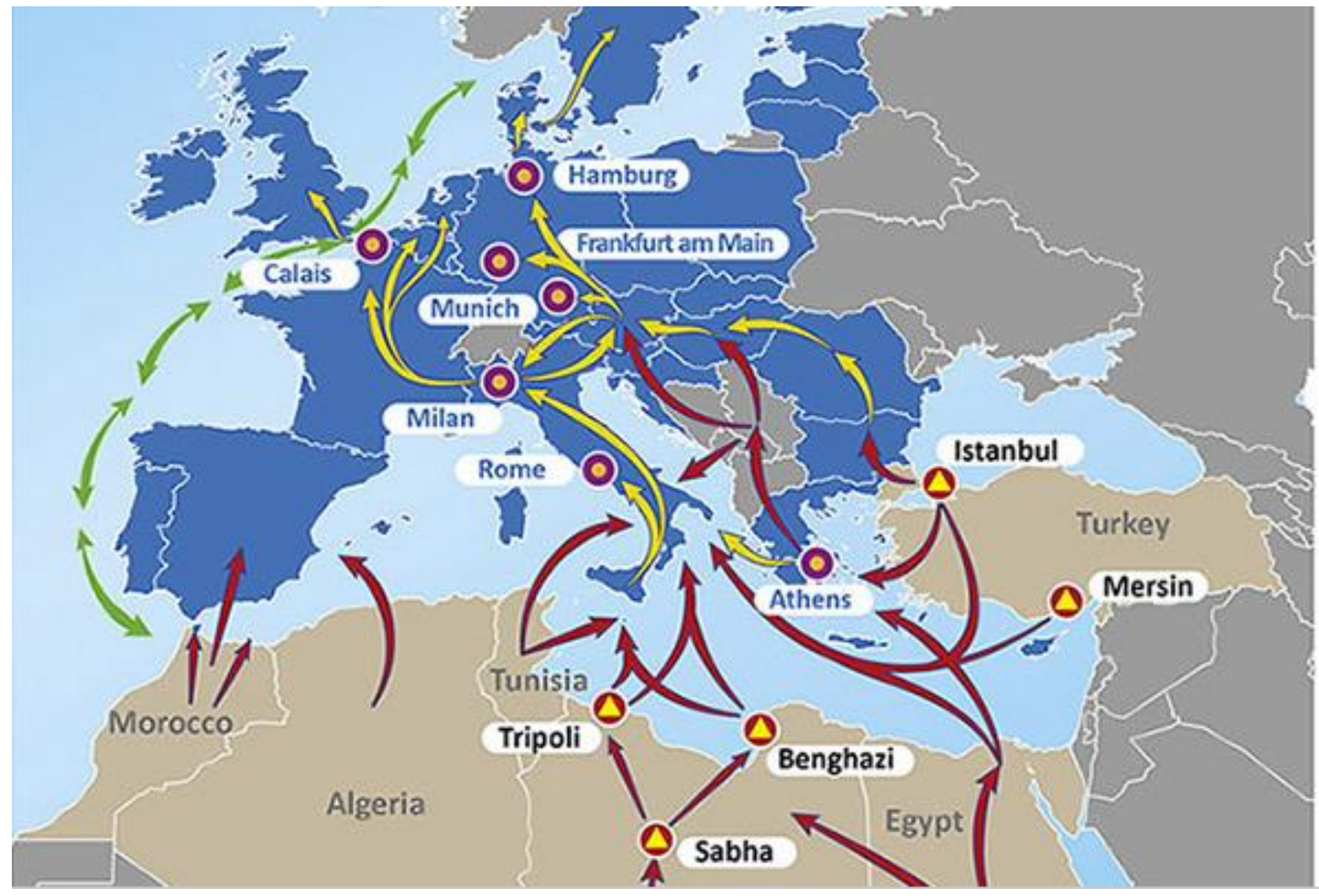

Fig. 2. Migration routes to the primary country of arrival, and subsequent refugee movements inside Europe

\section{Source: Katehon think tank. Geopolitics \& Tradition (2017)}

There are two types of people's migration: illegal migration (taking risk by themselves, with various options) and people smuggling (paying somebody to get to the target destination). Illegal immigrants are the people who have come to another country without a visa, temporary or permanent residence permit. The migration of people becomes illegal when they cross national borders without the permission from the national authorities. Refugees who try to enter another country in illegal ways by risking their own well-being, health and 
The International Journal

ENTREPRENEURSHIP AND SUSTAINABILITY ISSUES

ISSN 2345-0282 (online) http://jssidoi.org/jesi/

2018 Volume 5 Number 3 (March)

http://doi.org/10.9770/jesi.2018.5.3(16)

life are usually those whose basic physical and security needs are not satisfied, but they are not necessarily persecuted people. Individuals suffering from hunger or financial deprivation may also fall under this category.

The EU's position is to provide refugees with an asylum only if these illgeal immigrants-refugees will officially submit application documents and further on will be considered as eligible candidates for asylum.

There are distinguished two groups of illegal immigrants:

1. Refugees who were given a legal asylum. Supported by the EU or other countries, these refugees are transported by passenger transport to their destination points.

2. Refugees who do not come from the world's current "hot spots" and war zones. These refugees are not persecuted and unlikely to receive an asylum status or will not even apply for it and finally will be sent to their own country. As well as persons who are suspicious, offended the laws of their "original country", deliberately destroyed their identification documents, or simply out of great fear or distrust, attempt to find carriers offering "human trafficking", or secretly and illegally break into vehicles with a hope to reach their country of destination. Refugees of this type are the ones that cause the greatest damage to companies providing transportation services.

\section{Role of human factor in transportation process}

Even if migrants use different first paths of migration to the EU (Mediterranean sea or South Eastern), once they reach Europe, everyone travels using land transport, as it is essential and connective movement unit between EU countries.

Transportation is one of the most important factors in the global economy as it is a tool for moving product from less useful place to more useful pace, creating added value, changing the product's location as needed. The same is truth about the passenger transportation. Transportation assures necessary level of mobility and opens broad prospects for particular human being.

The transportation is the part of logistics and it is the main link between all of the stages of the supply chain. Transportation is the base of efficiency and economy in business logistics and expands other functions of logistics system. In addition, a good transport system performing in logistics activities brings benefits not only to service quality, but also to the company's competitiveness.

Land logistics is a very important link for logistics activities. It extends the delivery services for air and maritime transport from airports and seaports. The most positive characteristic of land logistics is the high accessibility level in land areas.

Road freight transport is the only transport mode, which ensures transportation from door to door. Compared to other transportation modes (sea, rail, air), road transport used worldwide has less limits of path restrictions. It is much more flexible, and is the best solution for meeting price and speed ratio.

However, road freight transportation is one of the most unsafe methods for moving goods. It faces a lot of dynamic risks. 
Risk typologies are analysed by S. Tang and M. Nurmaya Musa (2011) and P. Kouvelis, Ch. Chambers and H. Wang (2009). The authors point out that the overall external risk consists of the following: environmental, industrial and organizational factors. According to S. Rao and T. J. Goldsby (2009), these factors have effects on risk proneness in a supply chain.

Environmental risk variables are the ones that have a direct impact on the overall business context over all industries (Ritchie \& Marshall, 1993). Although this effect may be different and may be affected by different process areas, the underlying assumption is that the uncertainty created in the environment can give rise to some degree of insecurity (Kouvelis et al., 2009). According to K. Miller (1992), general environmental variables include political instability, government policy instability, macroeconomic uncertainties, social uncertainties, and natural uncertainties.

Such supply chain processes as transportation are not fully protected against different types of risks that may affect such negative consequences as delays, additional costs, and pollution. According to B. E. Asbjørnslett et al. (2008), threats in a supply chain can be divided into accidental and deliberate. Also, supply chain risks can be classified into operational risks and disruption risks.

Operational risk is associated with inherent uncertainty, such as unclear customer needs, vague supply planning, fluctuations in costs and demands.

Disruption risk is linked to major disruptions due to natural or man-made disturbances, disasters or catastrophes (Tang \& Nurmaya Musa, 2011). Nowadays one of the most topical, but yet not fully covered disruption risk that may have an impact on separate processes of the supply chain (transportation in particular) is associated with human factor and his activities.

Authors (Helander, 2006; Hollnagel, 2014; Karwowski, 2006) refer to the human factor as an area of ergonomics examining human relationships, opportunities and drawbacks in a workplace, but not as a separate factor impacting other than workplace process results.

In accordance with the above-mentioned authors, it is possible to provide a definition to a human factor: human factor - is a factor that determines human judgement, limited by his psychophysiological capabilities and is expressed through his/her behaviour and attitude.

A human may become unpredictable and incapable of controlling due to his/her ability to reason and rely not only on instincts.

Environmental conditions are one of the most important aspects defining human reasoning. A human does not only reside in the environment, interacts with it, but also changes it by participating and creating diverse processes. Certain changes in turn relate to physical and mental personality traits, stress, satisfaction, illnesses, pleasure, etc. (Dul et al., 2012). The accumulated complex of certain environmental factors may encourage a person to make certain decisions and take up actions. People, who are most likely to commit a crime, usually are the ones, who do not possess any assets and, therefore, often feel like they have nothing to lose. Such people are usually confused, not aware of what behaviour is socially acceptable, and are psychologically unstable. If a person is hungry, does not have a shelter, or if he feels threatened, he is ready for anything, without taking into consideration whether his actions are right or wrong, legal or not. 
Illegal actions made by human factor in transportation process might lead to the disruptions of entire supply chain, which may prevent economic growth of business entities, and, therefore, must be evaluated as source of risk.

\section{Description of applied methodology and key results of conducted research}

In order to illustrate risks associated with human factor and might occur during the transportation process, well known problem case dealing with illegal immigrants along the route France - UK, was chosen. The main aim of conducted research was to to highlight the tendencies of intrusions to the road freight transport unit and identify riskiest spots, where such incidents take place.

A questionnaire-survey method was applied. Managers and specialists of European international freight companies that were transporting cargo to the United Kingdom were presented with questionnaires.

A research questionnaire consisted of 2 blocks to determine the specifics of certain phenomena.

The first block of questions was aimed at defining the tendencies of illegal immigrant's intrusions into road freight transport units moving in the direction of the UK through the port of Calais.

The second block of questions was aimed at identifying the most risky locations and creation of the risk-map representing the most risky hotspots, where the level of intrusions is the highest.

The research was conducted verbally and in written. The questionnaire was sent to 41 representatives; however, due to only 17 fully completed and returned questionnaires, a verbal interview was carried-out to receive additional 19 questionnaires. Overall, 36 respondents took part in the research.

First, the tendencies of illegal immigrant's intrusions into road freight transport units were investigated.

One of the first questions was whether transport companies have faced with intrusions of illegal immigrants. The results have shown that this problem is particularly relevant. $92 \%$ of companies noted that they had encountered with the problem of intrusions into road freight transport units.

Analysis of data obtained during the survey proved that $72 \%$ of accesses into the road freight transport unit on its route to UK happened secretly (unit was intruded). Other $11 \%$ of accesses happened because the driver of road freight transport unit accepted certain reward for the assistance to immigrants to get to UK in his transport unit without being noticed. $6 \%$ of accesses took place because drivers were threatened. The remaining $11 \%$ of all events happened because of unknown reasons. This situation is presented in the figure below (see figure 3 ).

Results of research also proved that majority of illegal migrants tend to form smaller or larger groups rather than try to access road freight transport unit alone. In $89 \%$ of all access cases there were detected more than 1 illegal intruder. This is because "team-work" facilitate process of intrusion.

More deep analysis of this phenomenon revealed that:

- only in $17 \%$ of all access cases only one illegal intruder was detected;

- in $42 \%$ of all access cases number of detected intruders varied from 2 to 5;

- in $22 \%$ of all access cases number of detected intruders varied from 6 to 10 ; 
- -in 6\% of all access cases number of detected intruders varied from 11 to 20;

- $\quad$-in $3 \%$ of all access cases number of detected intruders exceed 20 (see figure 4).

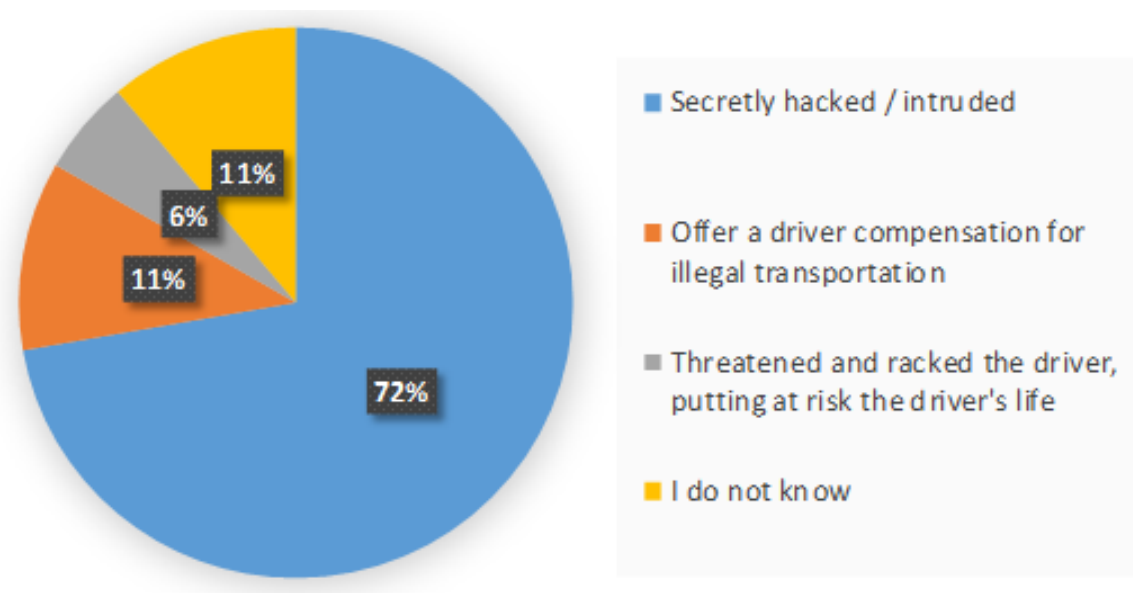

Fig. 3. The illegal migrant access to the road freight transport unit (compiled by the authors)

Source: compiled by authors

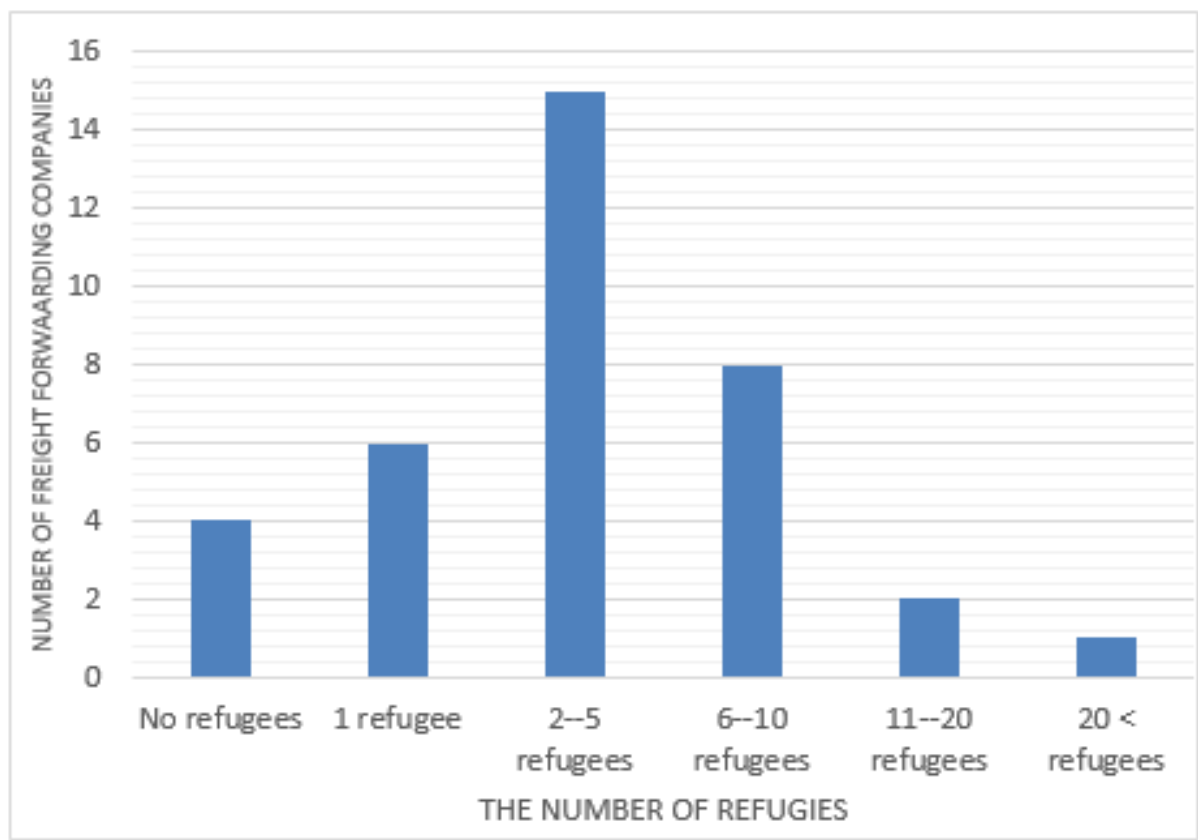

Fig. 4. Number of illegal immigrants intruded into a freight transport unit at the same time Source: compiled by the authors

Conducted research also revealed the main parts of road freight transport unit, where intruders were detected: 
- in $79 \%$ of all cases illegal intruders were detected in semitrailers;

- in $11 \%$ of all cases illegal intruders were detected in driver's cab;

- in $10 \%$ of all cases illegal intruders were detected in different parts of towing vehicle.

Results of the provided analysis also allowed identify time of the day, when frequency of intrusions is at its highest. Results are provided in figure 5. It is clear that majority of intrusions happens during the night time.

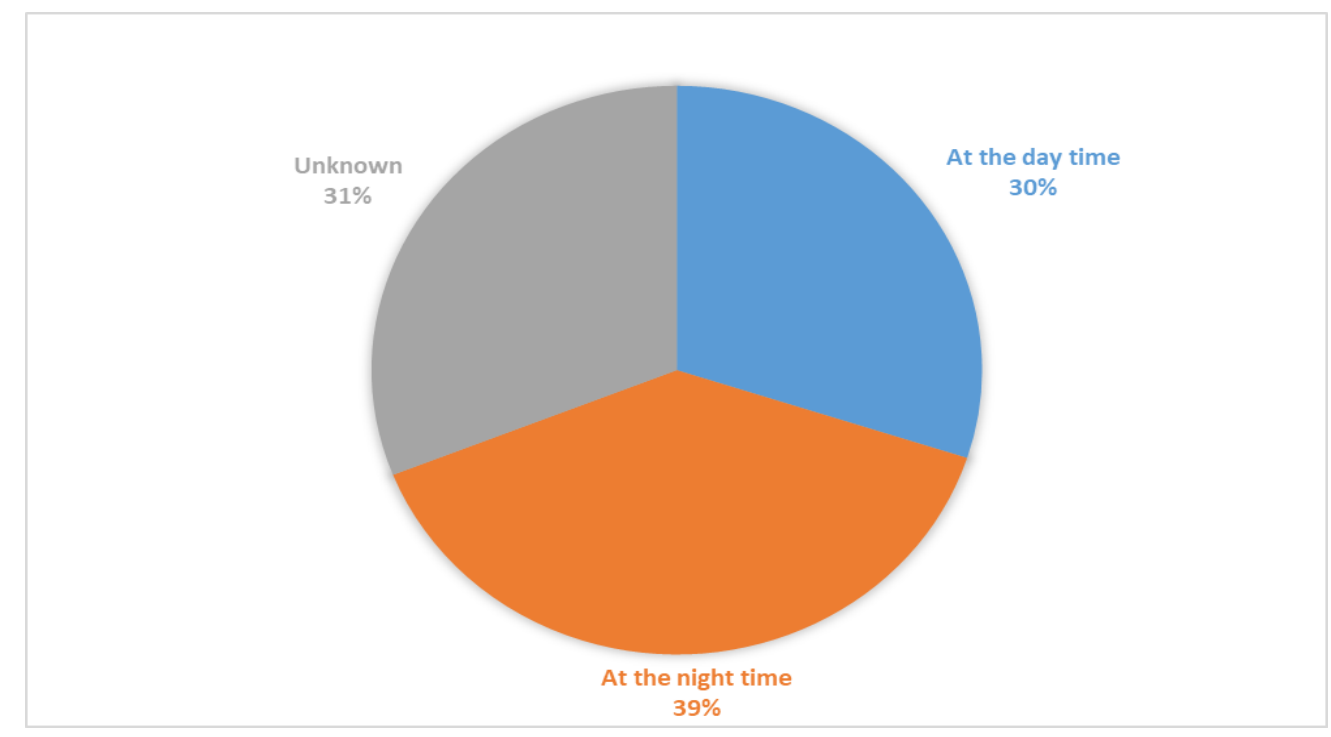

Fig. 5. The time of the day, when the intrusions of illegal immigrants occurs the most

Source: compiled by the authors

Next part of the research was dedicated to reveal the riskiest locations where intrusions might take place. Answers of the respondents allowed concluding that:

- $45 \%$ of intrusions happen when transport unit stays at insecure parking area;

- $25 \%$ of intrusions happen when transport unit slowly passes border area;

- $8 \%$ of intrusions happen at gas stations;

- $8 \%$ of intrusions happen at secure parking area;

- $14 \%$ of intrusions happen at unknown places.

Figure 6 presents the most frequent locations where fact of intrusion had happen. It is obvious, that illegal migrants most likely will enter the road freight transport unit during the border check (33\% of all incidents), during the transportation process ( $31 \%$ of all incidents) and during the driver's break stop ( $17 \%$ of all incidents). 


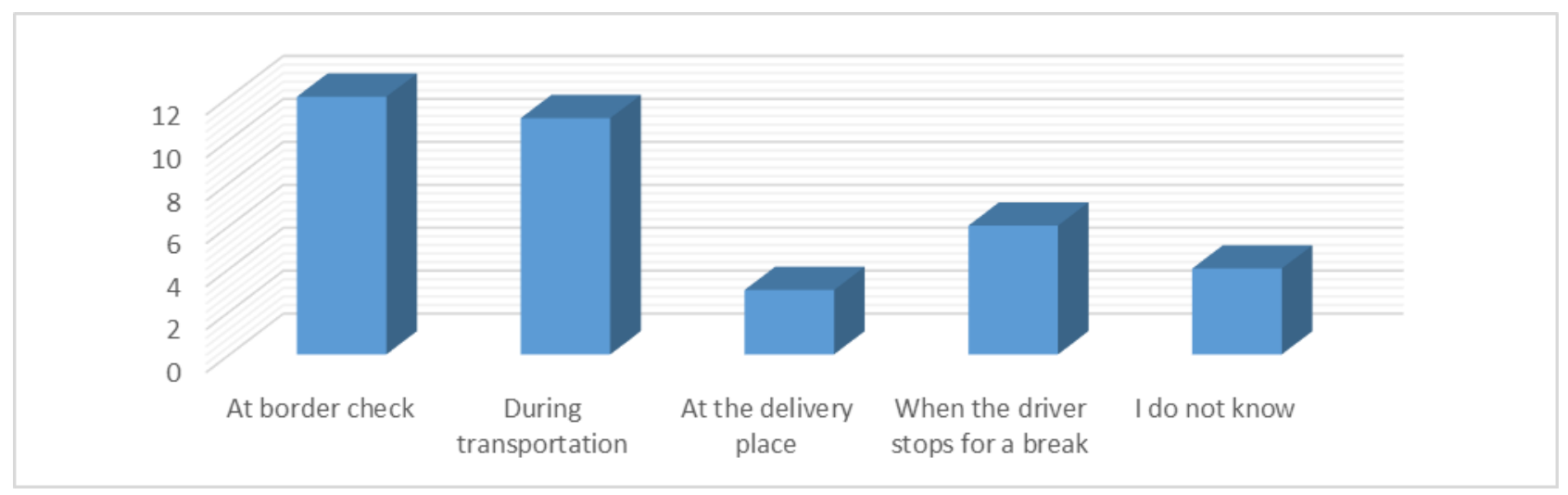

Fig. 6. The location of refugee intrusion to the truck

Source: compiled by the authors

Also questionnaire allowed identification of countries, where intruders invaded to vehicle (see figure 7). In this case the leading countries are France (47\% of incidents), Germany (18\% of incidents) and Spain (12\% of incidents).

At last, respondents identified the most dangerous cities and regions, where intrusions had happened more frequently (see table 1). Results provided in the table confirm that the most risky regions are in France, Germany, Spain, Belgium and the Netherlands.

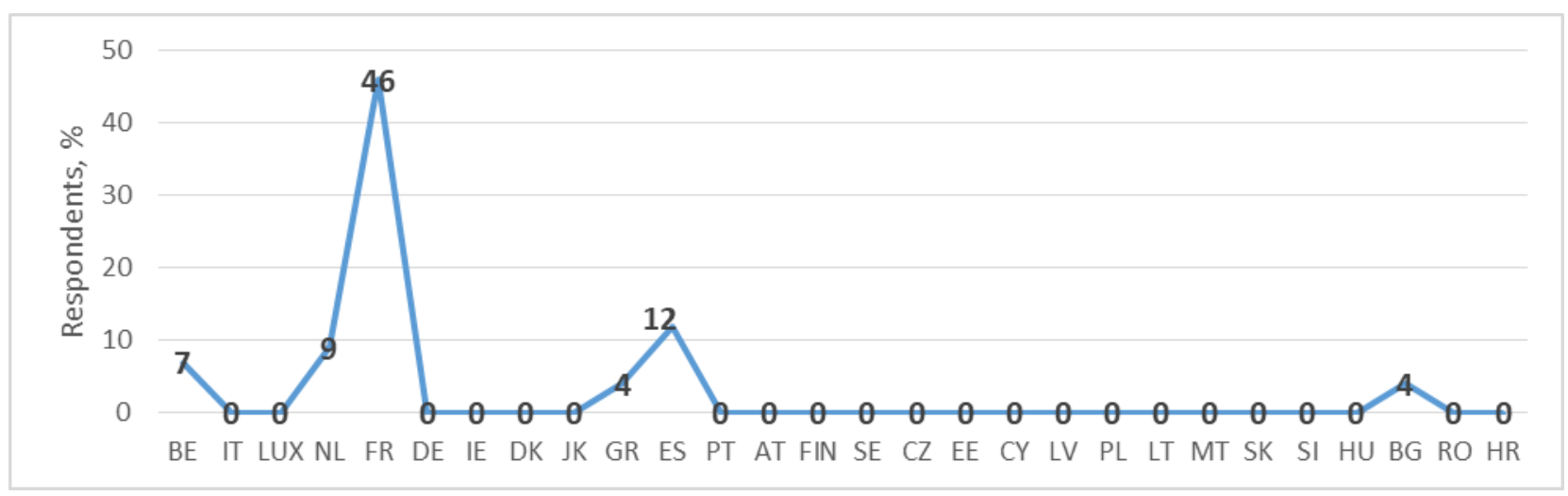

Fig. 7. Countries, where illegal immigrants have invaded to vehicle

Source: compiled by the authors

These findings formed the base for the development of risk -map ("crime hotspot") - the map which represents geographical areas associated with certain crimes. Such map is presented in figure 8 and is based on the data of identified locations of intrusions and frequency of intrusions at these locations. Conclusions can be made that concentration of these risky locations is higher on the northern part of France, Germany Belgium and the Netherlands, since there are much more hotspots, e.g. ports, which are gates to the UK. The most risky location and worst situation is in France, since here we have camp of immigrants situated next to Calais seaport. This is the most important hotspot, where immigrants form smaller or bigger groups and try to break into road freight transport units. 
Table 1. Cities, regions where refugees invaded into vehicle

\begin{tabular}{|c|c|c|}
\hline City or region & Country & The frequency of refugee intrusion \\
\hline Calais & France & 62 \\
\hline Coquelles eurotunnel & France & 32 \\
\hline Dunkerque & France & 41 \\
\hline Rotterdam & Netherlands & 12 \\
\hline Antwerp & Belgium & 12 \\
\hline Le Havre & France & 8 \\
\hline Lille & France & 5 \\
\hline Stuttgart & Germany & 4 \\
\hline Koln & Germany & 3 \\
\hline Bilbo & Spain & 3 \\
\hline Mannheim & Germany & 2 \\
\hline Vlissingen & Netherlands & 1 \\
\hline Terneuzen & Netherlands & \\
\hline Oostende & Belgium & \\
\hline Donostia & Spain & 1 \\
\hline
\end{tabular}

Source: compiled by authors

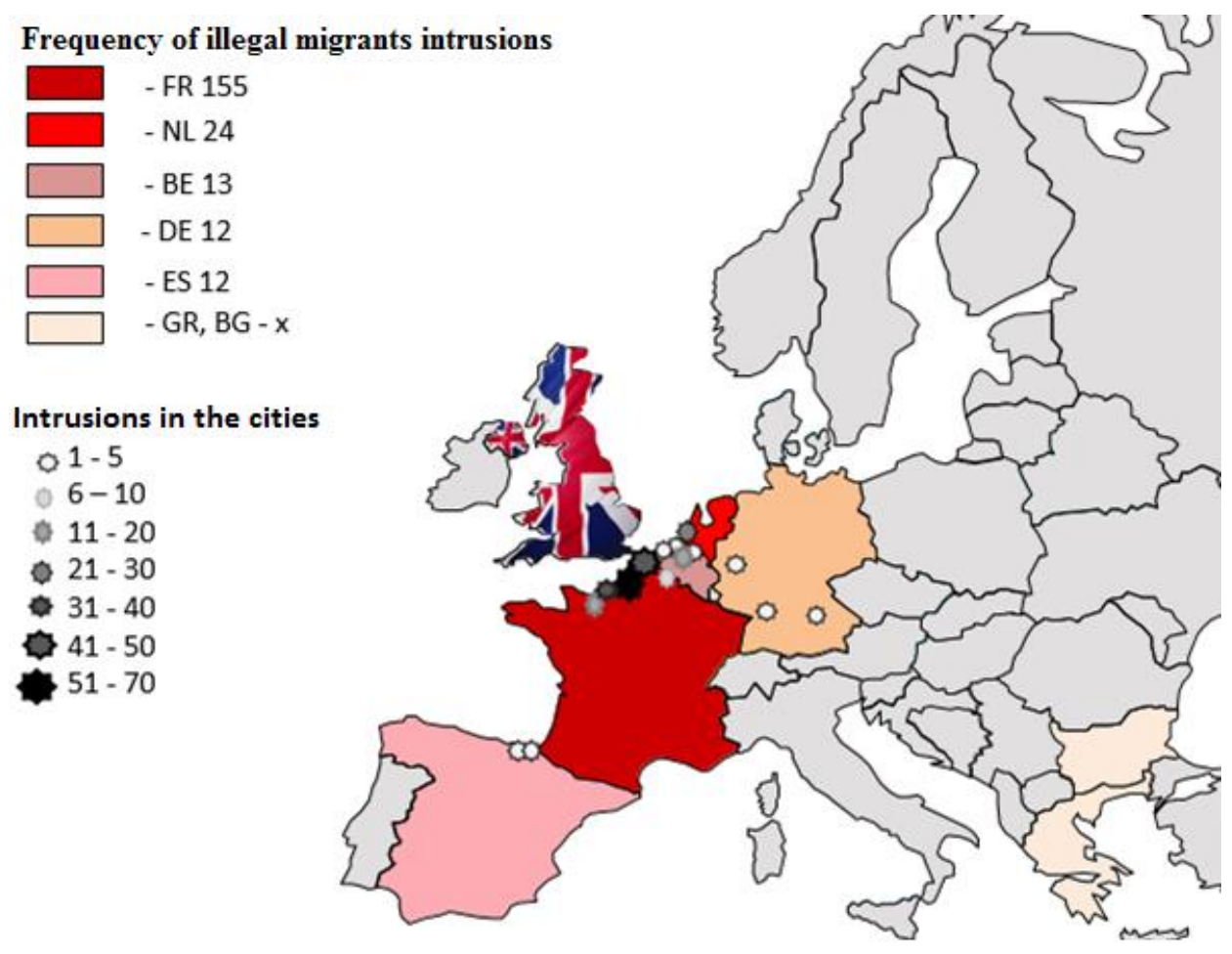

Fig. 8. The risk-map of illegal migrant's intrusions

Source: compiled by the authors 
The International Journal

ENTREPRENEURSHIP AND SUSTAINABILITY ISSUES

ISSN 2345-0282 (online) http://jssidoi.org/jesi/

2018 Volume 5 Number 3 (March)

http://doi.org/10.9770/jesi.2018.5.3(16)

\section{Conclusions}

Migration is one of the daily processes in people's lives. Transport and migration are inseparable from one another; however, the transfer of a person to another place, disobeying the law, is a criminal act. That's why refugees and illegal immigrants are elements of disruption risks and deliberate threat. Due to their unpredictable actions they are classified as an economic-political risk group. It is an environmental risk factor affecting transport in certain geographic sectors.

The World Economic Crisis has increased such processes as poverty, discrimination and war, and, as a consequence, many refugees from Africa, Middle East, Asia started to immigrate to Europe. A long-time frame for assessing asylum applications or frequent rejections encourages refugees to migrate illegally, by intruding road freight transport units, to cross the border of their chosen European country.

The intrusion of illegal immigrants into road freight vehicles to cross borders of EU countries without being noticed has caused a great deal of damage to road freight transportation companies, involving property and cargo damage, physical and psychological violence against drivers, etc. Disturbances that happen because of illegal immigrant's intrusions have even more serious consequences: the disposal of cargo due to illegal immigrant intrusions into freight vehicles, termination of factory operations, dropping of sales, delays in the production, or product delivery into the market.

Results of conducted study prove that intrusions into the road freight transport units along the route France - UK became better organized and planned. European road freight companies are taking preventive measures in order to reduce or avoid such incidences; however, they are unlikely to be effective enough. Private sector is not able to control the risks of illegal immigrants through its preventive measures alone. Risk map, developed on the basis of results of conducted investigation, identifies main hot spots where majority of incidents happens, as well as key peculiarities of such incidents. This might serve as initial background for the cooperation between private and public sector and joining their efforts towards elaboration of common plans and actions necessary for solving this problem in the nearest future.

\section{References}

Androniceanu, A. (2017). Hospital management based on the relationship between doctors and patients. Administratie si Management Public, (29), 41-53. Retrieved from http://www.ramp.ase.ro/en/_data/files/articole/2017/29-03.pdf

Asbjørnslett, B. E., Ritchie, B., Ritchie, R., \& Zsidisin, G. (2008). Assessing the Vulnerability of Supply Chains. In Supply chain risk: a handbook of assessment, management, and performance (Vol. 124, p. 157). Springer. http://doi.org/10.1007/978-0-387-79933-9

Bade, K. J., \& Münz, R. (2000). Migrationsreport 2000 : Fakten, Analysen, Perspektiven. Campus.

Banaitė, D., \& Tamošiūnienė, R. (2016). Sustainable Development: The Cirvular Economy Indicators' Selection Model. Journal of Security and Sustainability Issues, 6(2), 315-323. http://doi.org/10.9770/jssi.2016.6.2(10)

Carra, C.; Burlacu, S; Faggianelli, D. (2016). Violence within organizations in the health and medico-social sectors, comparative analysis France-Romania, Administratie si Management Public (27), 123-142.

Courgeau-Andevalelievre, D. (2016). Individual and Social Motivations for Migrations.

Courgeau, D., \& Lelièvre, E. (2006). Individual and social motivations for migration. Demography: Analysis and Synthesis, $345-359$. Retrieved https://www.researchgate.net/profile/Daniel_Courgeau/post/How_would_you_define_the_term_of_Translocality/attachment/59d62c 


\section{2bc49f478072e9dda5/AS:273542174707753@1442228945075/download/ch063.pdf}

Dul, J., Bruder, R., Buckle, P., Carayon, P., Falzon, P., Marras, W. S., van der Doelen, B. (2012). A strategy for human factors/ergonomics: developing the discipline and profession. Ergonomics, 55(4), 377-395. http://doi.org/10.1080/00140139.2012.661087

Eurostat. (2016). Retrieved November 15, 2016, from http://ec.europa.eu/eurostat/data/browse-statistics-by-theme

Harzig, C., Hoerder, D., \& Gabaccia, D. R. (2009). What is migration history? Polity. 181 p.

Helander, M. (2006). A Guide to Human Factors and Ergonomics, Second Edition - Martin Helander (2nd editio). NY: Taylor \& Francis. $414 \mathrm{p}$.

Hollnagel, E. (2014). Human factors/ergonomics as a systems discipline? "The human use of human beings" revisited. Applied Ergonomics, 45(1), 40-44. http://doi.org/10.1016/J.APERGO.2013.03.024

Karwowski, W. (Ed.). (2006). International Encyclopedia of Ergonomics and Human Factors, Second Edition - 3 Volume Set. CRC Press. http://doi.org/10.1201/9780849375477

Katehon think tank. Geopolitics \& Tradition. (2017). Retrieved January 11, 2017, from http://katehon.com/

King, R., \& Lulle, A. (2016). Research on Migration: Facing Realities and Maximising Opportunities, A Policy Review. Brussels. http://doi.org/10.2777/414370

Kobler, B. (2017). International Migration Report $2017 . \quad$ Retrieved from http://www.un.org/en/development/desa/population/migration/publications/migrationreport/docs/MigrationReport2017_Highlights.p $\underline{\mathrm{df}}$

Kot, S., Pigoń, Ł. (2014). Effective occupational counselling for the unemployed. Polish Journal of Management Studies, 10(1), 54-62.

Kouvelis, P., Chambers, C., \& Wang, H. (2009). Supply Chain Management Research and Production and Operations Management: Review, Trends, and Opportunities. Production and Operations Management, 15(3), 449-469. http://doi.org/10.1111/j.19375956.2006.tb00257.x

Masood, G., \& Nijkamp, P. (2017). A Brief Overview of International Migration Motives and Impacts, with Specific Reference to FDI. Economies, 5(3), 31. http://doi.org/10.3390/economies5030031

Miller, K. D. (1992). A framework for integrated risk management in international business. Journal of International Business Studies, 23(2), 311-331. http://doi.org/10.2307/154903

Oiarzabal, P. J., \& Reips, U.-D. (2012). Migration and Diaspora in the Age of Information and Communication Technologies. Journal of Ethnic and Migration Studies, 38(9), 1333-1338. http://doi.org/10.1080/1369183X.2012.698202

Rao, S., \& Goldsby, T. J. (2009). Supply chain risks: a review and typology. The International Journal of Logistics Management, 20(1), 97-123. http://doi.org/10.1108/09574090910954864

Reips, U. D., \& Buffardi, L. E. (2012). Studying Migrants with the Help of the Internet: Methods from Psychology. Journal of Ethnic and Migration Studies, 38(9), 1405-1424. http://doi.org/10.1080/1369183X.2012.698208

Ritchie, B., \& Marshall, D. V. (David V. (1993). Business risk management. Chapman \& Hall.

Shuaibu, M., \& Oladayo, P. (2016). Determinants of human capital development in Africa: a panel data analysis. Oeconomia Copernicana, 7(4), 523-549. https://doi.org/10.12775/OeC.2016.030

Świerczyńska, K. (2017). Structural transformation and economic development in the best performing sub-Saharan African states. Equilibrium. Quarterly Journal of Economics and Economic Policy, 12(4), 547-571. https://doi.org/10.24136/eq.v12i4.29 


\section{The International Journal}

ENTREPRENEURSHIP AND SUSTAINABILITY ISSUES

ISSN 2345-0282 (online) http://jssidoi.org/jesi/

2018 Volume 5 Number 3 (March)

http://doi.org/10.9770/jesi.2018.5.3(16)

Tang, O., \& Nurmaya Musa, S. (2011). Identifying risk issues and research advancements in supply chain risk management. International Journal of Production Economics, 133(1), 25-34. http://doi.org/10.1016/J.IJPE.2010.06.013

Tumalavičius, V., Nikolayevskyy, V., \& Endziņš, A. (2017). Issues of the State and Society Security (Part II): Management of Control Over Individual Criminal Processes. Journal of Security and Sustainability Issues, 6(4), 605-618. http://doi.org/10.9770/jssi.2017.6.4(6)

Tvaronavičienè, M., \& Černevičiūtè, J. (2015). Technology Transfer Phenomenon and its Impact on Sustainable Development. Journal of Security and Sustainability Issues, 5(1), 87-97. http://doi.org/10.9770/jssi.2015.5.1(7)

UNHCR. (2017). Retrieved January 11, 2017, from http://www.unhcr.org/

Walancik, M., Chmiel, M. (2014). Security as a goal of the state existence - conditions and contexts based on the case of Poland, Forum

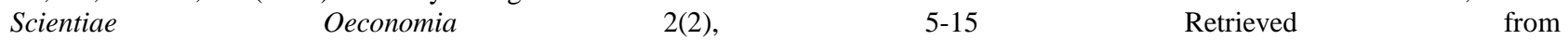
http://www.wsb.edu.pl/container/FORUM\%20SCIENTIAE/forum\%202014\%20nr\%202/1.m-walancik-m-chmiel.pdf

Margarita Marija LIETUVNIKE is MSc of Vilnius Gediminas Technical University and she is working at the international Freight forwarding company as a project manager (e-mail: margarita.smile@gmail.com). Her master thesis topic was related to illegal immirannt's impact on transportation process and it's management. Her research interests include human factor impact on transportation and logistics processes, and risks caused by illegal migration to European road freight transport.

ORCID ID: orcid.org/0000-0003-2644-5254

Aidas VASILIS VASILIAUSKAS is the Professor at the General Jonas Žemaitis Military Academy of Lithuania and associate professor of the Logistics and Transport Management Department at Vilnius Gediminas Technical University (e-mail: aidas.vasilisvasiliauskas@vgtu.lt). He obtained PhD degree in transport engineering from Vilnius Gediminas Technical University in 2004. His research interests include over than 18 Years of experience in a field of transport engeneering, transport systems and transport management. Aidas Vasilis Vasiliauskas has over 70 scientific publications on different topics related with transport system, transportation and warehousing processes, supply chain management.

ORCID ID: orcid.org/0000-0002-4547-3966

Virgilija VASILIENÉ-VASILIAUSKIENE is associated professor of the Logistics and Transport Management Department at Vilnius Gediminas Technical University Vilnius Gediminas Technical University (e-mail: virgilija.vasiliene-vasiliauskiene@ vgtu.lt). She obtained $\mathrm{PhD}$ degree in management from Vilnius Gediminas Technical University in 2006. Her research interests include total quality management, logistics processes, supply chain management. Virgilija Vasilienè-Vasiliauskienè has over 50 scientific publications on different topics related with on the topic of transportation, quality management and supply chain management.

ORCID ID: orcid.org/0000-0003-2360-4256

Jolanta SABAITYTÉ is lecturer at the Business Technologies and Enterpreneurship Department at Vilnius Gediminas Technical University and Ingeneering Management Department at the General Jonas Žemaitis Military Academy of Lithuania (e-mail: jolanta.sabaityte@vgtu.lt). She obtained her PhD degree in management from Vilnius Gediminas Technical University in 2017. Her research interests include supply chain management, electronic business and management of strategic decisions. Jolanta Sabaityte has teaching experience in Lithuania, Germany, Russia and Ukraine. She actively participates in scientific conferences as a speaker and publishes results of scientific researches in various national and foreign scientific research journals. J. Sabaityte also worked as a researcher in European Commission TEMPUS project "Two Cycle E-commerce Curricula to Serve Information Society in Russia, Ukraine and Israel" (ECOMMIS).

ORCID ID: orcid.org/0000-0003-1009-4111

Copyright $@ 2018$ by author(s) and VsI Entrepreneurship and Sustainability Center This work is licensed under the Creative Commons Attribution International License (CC BY). http://creativecommons.org/licenses/by/4.0/ (c) (7) Open Access 